\title{
ASPECTS OF PLASMA BIOCHEMISTRY AND INTESTINAL HEALTH OF WEANED PIGLETS FED DIETARY EXTRUDED LINSEED AND WALNUT MEAL MIXTURE
}

\author{
Anca Gheorghe*, Mihaela Hăbeanu, Nicoleta A. Lefter, Mihaela Dumitru, Daniela M. Grigore \\ National Research-Development Institute for Animal Biology and Nutrition (INCDBNA), \\ 077015 Balotesti, Calea Bucuresti no. 1, Romania
}

\author{
${ }^{*}$ Corresponding author: \\ Phone: +40213512081 \\ Fax: +40213512080 \\ E-mail address: anca.gheorghe@ibna.ro
}

\begin{abstract}
The effects of dietary extruded linseed (ELS):walnut meal (WM) mixture (8:1) on some plasma parameters and intestinal health in weaned piglets was investigated. Forty piglets (Topigs hybrid; body weight $B W=8.02 \pm 0.82 \mathrm{~kg}$ ), age $30 \pm 3$ days, were divided into 2 groups and fed 2 diets: control (C, based on corn-triticale-soybean meal (SBM)) and experimental (ELS:WM, where the ELS:WM mixture 8:1 partially replaces SBM). Blood samples were collected at 7 and 21 days postweaning (PW). A chemistry analyzer was used to determine the plasma lipid (total cholesterol, T-Chol; HDL-cholesterol, HDL-C; triglycerides, TG), mineral and enzymatic profile. Microbial populations from fecal samples were determined by counting the colonies obtained on selected media. There was no effect of dietary mixture inclusion on plasma parameters at 7 and 21 days $P W(P>0.05)$. The plasma HDL-C concentration was positively correlated with the alpha-linolenic (ALA) fatty acids content of diet at days $7(r=0.94, P<0.0001)$ and $21 \mathrm{PW}(r=0.89, \mathrm{P}<0.0001)$, while at day $21 \mathrm{PW}$ the T-Chol $(r=0.52$, $P=0.08)$ and TG $(r=0.54, P=0.07)$ tended to be influenced by the dietary treatment. Fecal score ( $F S)$ decreased at day $7 \mathrm{PW}(\mathrm{P}>0.05)$, and at day $21 \mathrm{PW}$ a tendency to decrease $\mathrm{FS}$ as a response to dietary mixture addition was observed $(P=0.07)$. The tested dietary mixture positively affected the microbial fecal populations by decreasing the Staphylococcus spp. $(P=0.001)$, $E$. coli $(P<0.0001)$ and fungi $(P=0.004)$, also tended to increase the Lactobacillus spp. $(P=0.08)$. In conclusion, the dietary mixture could be an alternative to partially replace SBM in piglet's diet due to positive biochemical response and intestinal health.
\end{abstract}

Key words: extruded meal, dietary mixture, enteritis, fecal microflora, plasma parameters, piglets

\section{INTRODUCTION}

The gut of piglets during weaning period is associated with changes of size, protein turnover rates, microbiota, digestive and immune function (Pluske et al., 1997). As a result, plasma markers, as indicators of health status, could be altered as well. The stress-generating factors specific to weaning period slow the growth rate caused by high diarrhea incidence and imbalanced intestinal microecology (Giang et al., 2012). Growth and disorders, weakness or high mortality rate are manifestations of the effect of immunity function, inappro- priate adaptation of the thermoregulation system, incomplete digestive system development as well as secondary infections caused by pathogens. For example, enteric diseases that are often associated with different Escherichia coli bacteria cause $1.5-2.0 \%$ post-weaning mortality (Kiers et al., 2003; Jansman et al., 2007). Many authors have shown that different protein sources or higher level of dietary proteins provide a substrate for pathogen bacteria to proliferate (Nyachoti et al., 2006; Hăbeanu et al., 2015), causing wa- 
tery feces (Wellock et al., 2008) and affecting the health and performance of piglets (Che et al., 2012). Thus, the presence of by-products (e.g. linseed, walnut by-products) in the diet, with various combinations of phytonutrients and biologically active substances ( $\mathrm{n}-3$ fatty acid, $\mathrm{FA}$; alpha-linolenic, ALA; antioxidants; lignans; dietary fiber) with beneficial effects on animal health, could offer benefits with respect to the control of diarrhea and feed efficiency in piglets.

Linseed is among the most known polyunsaturated fatty acid (PUFA) source which led to beneficial effect on health (Zhan et al., 2009). Several biological activities, such as beneficial effects on serum parameters, immune mediators and anti-inflammatory responses in humans and animals were reported using linseed diets (Barcelo-Coblijn and Murphy, 2009; Farmer et al., 2009; Țăranu et al., 2014). Moreover, walnut meal is a nutrient-dense food with exceptional nutrient profile which has been investigated for its antiatherogenic, anti-inflammatory and antioxidant activities (Mar-tínez et al., 2010; Chen et al., 2012).

Due to the complementary effects, we propose as a solution a mixture of linseed and walnut meal (8:1) as an alternative to improve the energy, amino acids and fatty acid balance of the compound feed which could additionally be beneficial in minimizing some of the adverse effects of weaning stress period. Therefore, we aimed to investigate how this mixture influences certain plasma parameters and intestinal health.

\section{MATERIALS AND METHODS}

The trial procedures were approved by the Animal Care Committee of the INCDBNA Balotesti (Romania) and pigs were handled in conformity with EU Directive 2010/63/EU (OJEU, 2010).

\section{Animals and diets}

A total of forty weanling piglets Topigs [O Large White $x$ Hybride (Large White $x$ Pietrain) $\times \delta$ Talent, mainly Duroc], average body weight (BW) $8.02 \pm 0.82 \mathrm{~kg}$, age $30 \pm 3$ days, housed in environmentally controlled conditions, were randomly as- signed into 2 groups (male : female, 1:1) with 2 replicates each (10 piglets/pen). Piglets had free access to feed and water for all period.

Dietary treatments consisted from a control diet ( $C$, based on corn-triticale-soybean meal (SBM)) and an experimental diet (ELS:WM, based on corn-triticaleSBM and a mixture of extruded lin-seed: walnut meal $(8: 1)$ that replaced $27.8 \%$ of SBM).

The gross chemical composition of dietary mixture ELS:WM used in this study was $910 \mathrm{~g} / \mathrm{kg}$ dry matter, $274 \mathrm{~g} / \mathrm{kg}$ crude protein, $143 \mathrm{~g} / \mathrm{kg}$ crude fat, $156 \mathrm{~g} / \mathrm{kg}$ crude fiber and $14.95 \mathrm{MJ} / \mathrm{kg} \mathrm{ME}$.

The diets were isocaloric and isonitrogenous, formulated based on corn, triticale, soy-bean meal, corn gluten, milk replacer, sun-flower oil, essential amino acids (L-lysine and DL-Methionine), choline premix, phytase and vitamin-mineral premix, according to nutrient requirements of pig's hybrid (Topigs, 2012).

The analyzed composition and fatty acid profile of diets are presented in Table 1. As expected the experimental diet contained a high concentration $(24.58 \%)$ of C18:3 n-3 and a ratio of 1.67:1 of LA:ALA as the results of dietary mixture addition.

\section{Chemical analysis}

The chemical composition of feed ingredients and diet samples was determined by standardized methods according to EU Regulation 152/2009 (OJEU, 2009): dry matter (SR ISO 6496:2001), crude protein (SR EN ISO 5983-2:2009), crude fat (SR ISO 6492:2001), crude fibre (SR EN ISO 6865:2002), crude ash (SR EN ISO 2171:2010).

The fatty acids profile of feed ingredients and diets were determined by gas chromatography, as described Hăbeanu et al. (2014; 2015).

\section{Blood sampling and analysis}

Blood samples were collected on days 7 and 21 post-weaning from 8 piglets per group ( 4 male and 4 female) by jugular venipuncture in heparinized vacutainer tubes $(6 \mathrm{~mL})$ and centrifuged $(3000 \mathrm{rpm}$ for $15 \mathrm{~min}$ ) for plasma separation. 
A chemistry analyzer (Spotchem EZ SP4430, Arkray, Japan) and specific commercial kits were used to determine the plasma biochemical parameters (total cholesterol, T-Chol; HDL-cholesterol, HDL-C; triglycerides, TG; calcium, Ca; magnesium, Mg; inorganic phosphorus, IP; glutamyl oxaloacetic transaminase, GOT; glutamyl pyruvic transaminase, GPT; creatine phosphokinase, CPK; gamma-glutamyl transferase, GGT).

\section{Faeces sampling and analysis}

During the first week post-weaning samples of piglet feces were daily collected in Petri dishes, and stored at $-4{ }^{\circ} \mathrm{C}$ until microbiological analyses (Hăbeanu et al., 2015).

Fecal microbial populations (total fungi, Staphylococcus spp., E. coli, Lactobacillus spp., Salmonella) were determined on selected media using a colony counter. The results were expressed as a logarithm (base 10) of colony-forming units per gram of sample. For the calculation of the fecal score the consistency of piglets feces was evaluated visually daily according to a scoring system from 1 to 3 (1, soft feces; 2, mild diarrhea; 3 , severe diarrhea). The inci-dence of diarrhea (\%) was calculated as average number of days with diarrhea related to the total monitoring days (Hăbeanu et al., 2017).

\section{Statistical analysis}

The results are given as means and standard error of the mean (SEM). All experimental data were analyzed using the GLM procedure of the software SPSS (IBM SPSS Statistics version 20.0, 2011). One-way analysis of variance (ANOVA) with the Tukey's comparison test was used to evaluate statistical significance of differrences between the dietary treatments.

Differences were considered significant at $P \leq 0.05$. The individual was considered as experimental unit in case of plasma biochemical analysis and replicate for the fecal parameter determinations. The bacterial counts were transformed $(\log 10)$ before statistical analysis.

Table 1.

Chemical composition and fatty acid profile of piglet diets

\begin{tabular}{lcc}
\hline & & Dietary groups \\
\hline Chemical composition (g/kg) & C & ELS:WM \\
\cline { 2 - 3 } Crude protein & 895.2 & 891.9 \\
Lysine & 187.5 & 183.3 \\
Methionine+Cystine & 12.0 & 12.0 \\
Calcium & 7.2 & 7.2 \\
Phosphorus & 9.0 & 9.0 \\
Crude fat & 7.8 & 7.8 \\
Crude fiber & 47.5 & 47.3 \\
Metabolisable energy, ME (MJ/kg) & 36.9 & 43.0 \\
\hline Fatty acid (\% of total FAME) & 13.64 & 13.63 \\
\hline C14:0 (myristic) & & 0.10 \\
C16:0 (palmitic) & 0.16 & 9.11 \\
C16:1 (palmitoleic) & 12.99 & 0.16 \\
C18:0 (stearic) & 0.16 & 2.80 \\
C18:1cis-9 (oleic) & 2.89 & 21.38 \\
C18:2n-6 (linoleic LA) & 26.53 & 41.00 \\
C18:3n-3 (alpha-linolenic ALA) & 51.54 & 24.58 \\
C18:4n-3 (stearidonic) & 4.59 & 0.27 \\
C20:2n-6 (eicosadienoic) & 0.35 & 0.20 \\
C20:4n-6 (arachidonic) & 0.28 & 0.12 \\
Total SFA & 0.25 & 12.01 \\
Total MUFA & 16.04 & 21.54 \\
LA:ALA ratio & 26.69 & 1.67 \\
\hline - & 11.23 & \\
\hline
\end{tabular}

C - control diet, ELS:WM - extruded linseed:walnut meal diet

"ME calculated using regression equations (NRC, 1998)

Results are given as mean ( $n=3)$; FAME: fatty acids methyl esters; SFA: Saturated fatty acids; Total SFA = C14:0

+ C16:0 + C18:0; MUFA: Monounsaturated fatty acids; Total MUFA = C16:1 + C18:1cis-9 


\section{RESULTS AND DISCUSSION}

\section{Plasma biochemistry}

The effect of dietary extruded linseed: walnut meal mixture (8:1) on plasma bio-chemistry parameters of weaned piglets is shown in Table 2. There was no evident effect of dietary mixture inclusion on plasma lipid profile (T-Chol, HDL-C and TG), at days 7 and $21 \mathrm{PW}(\mathrm{P}>0.05)$, the values obtained range in normal limits (Merck Veterinary Manual (Merck\&Co. 2010; Perri et al., 2017).

Blood cholesterol levels are influenced by genetic factors and environmental conditions, including nutrition (Hanczakowski et al., 2009). The levels of HDL-Cholesterol in pig's plasma should represent at least $40 \%$ of total cholesterol concentrations (Winnicka, 2011), a decrease in the HDL fraction below this value is undesirable. In the current study, the HDL fraction was higher than $40 \%$ from the total cholesterol and was not affected by the dietary treatments at day 7 (45.14\% ELS:WM vs. $41 \%$ C group), or at day 21 (49.72\% ELS:WM vs. $50.61 \%$ C group).

In addition, the results of our study showed that the plasma HDL-Cholesterol concentration was positively correlated with the ALA fatty acids content of diet at days $7(r=0.94, P<0.0001)$ and 21 post-weaning $(r=0.89, P<0.0001)$, while at day 21 postweaning the $\mathrm{T}-\mathrm{Chol}(\mathrm{r}=0.52, \mathrm{P}=0.08)$ and TG $(r=0.54, P=0.07)$ concentration tend to be influenced by the ALA fatty acids content of the dietary treatment.

Recently, Gheorghe et al. (2018) reported that a dietary mixture consisted of extruded linseed:walnut meal (8:1) improved the growth performance and had a positive effect on plasma protein profile, especially on urea nitrogen of piglets in weaning period. The improvement in growth performance of piglets could be attributed to the anti-inflammatory properties of $n-3$ PUFA and bioactive compounds with benefits on health status contained by the tested dietary mixture. Plasma mineral and enzyme profile at days 7 and $21 \mathrm{PW}(\mathrm{P}>0.05)$ were not affectted by feeding with the dietary mixture, the concentrations being in normal range (Merck Veterinary Manual, 2010).

\section{Intestinal health}

The major cause of suboptimal production and mortality of piglets in the first 2 weeks after weaning is post-weaning diarrhea (Pluske et al., 2003). Table 3 presented the effect of feeding extruded linseed: walnut meal mixture (8:1) on fecal scores (FS) and incidence of diarrhea (ID) in weaned piglets. Fecal score reflects the digestive health of piglets, a high score indicates high incidence of diarrhea (Wen et al., 2018). In our study, fecal score was decreased by $10.71 \%$ at day 7 PW $(P>0.05)$, and at day $21 \mathrm{PW}$ it was observed a decreasing tendency by $17.05 \%$ $\mathrm{FS}$ as a response to dietary mixture addition $(P=0.07)$. Consequently, the incidence of enteritis also decreased as a result of feeding with the dietary mixture, but the difference was not significant $(P>0.05)$. These findings are partially consistent with previous studies of Hăbeanu et al. (2017) who reported that the use of dietary peas:linseed mixture (3:1) slowly increased $(P>0.05)$ the bacterial count of feces and caused a higher incidence of diarrhea after 2 weeks post weaning compared to classical diet.

The effect of feeding extruded linseed: walnut meal mixture (8:1) on fecal microbial populations at 7 days post-weaning $(\log 10 \mathrm{cfu} / \mathrm{g})$ are given in Table 4.

The results shown that dietary mixture addition positively affects the bacterial populations of the faces by decreasing the Staphylococcus spp., (-1.31\%; $\mathrm{P}=0.001)$, E. coli $(-5.27 \% ; \mathrm{P}<0.0001)$ and total fungi $(-9.52 \% ; P=0.004)$, and tend to increase Lactobacillus spp. (+6.84\%; $\mathrm{P}=0.08)$.

It is known that Lactobacillus spp. is considered as a beneficial bacterium for the balance of intestinal microbiota, due to its health promoting effects such as prevention of diarrhea and intestinal infections.

Previously, Konstantinov et al. (2006) in a study on intestinal microbiota of weaned piglets has shown that after weaning, $E$. coli concentrations increased while the number of Lactobacillus decreased. Therefore, our results showed an increase of Lactobacillus $(P=0.08)$ and a decrease of $E$. coli $(P<0.0001)$ in feces of weaned piglets and confirmed the reduced incidence 
Anca Gheorghe et al., Aspects of plasma biochemistry and intestinal health of weaned piglets fed dietary extruded linseed and walnut meal mixture, Food and Feed Research, 46 (1), 147-153, 2019

Table 2.

Plasma biochemistry parameters in weaned piglets fed dietary extruded linseed:walnut meal mixture $\underline{(8: 1)}$

\begin{tabular}{|c|c|c|c|c|c|c|}
\hline \multirow[b]{2}{*}{ Parameters } & \multirow[b]{2}{*}{ References } & \multirow{2}{*}{$\begin{array}{c}\text { Period post- } \\
\text { weaning } \\
\text { (days) }\end{array}$} & \multicolumn{2}{|c|}{ Dietary groups } & \multirow[b]{2}{*}{ SEM } & \multirow[b]{2}{*}{ P-value* } \\
\hline & & & C & ELS:WM & & \\
\hline \multirow{2}{*}{ T-Chol, mg/dL } & \multirow{2}{*}{$67.0-377^{2}$} & 7 & 77.30 & 82.63 & 4.17 & 0.569 \\
\hline & & 21 & 82.00 & 81.25 & 3.01 & 0.884 \\
\hline \multirow[b]{2}{*}{ HDL-C, mg/dL } & \multirow[b]{2}{*}{-} & 7 & 31.50 & 37.30 & 3.20 & 0.424 \\
\hline & & 21 & 41.50 & 40.40 & 2.04 & 0.810 \\
\hline \multirow{2}{*}{$\mathrm{TG}, \mathrm{mg} / \mathrm{dL}$} & \multirow{2}{*}{$33-50^{1}$} & 7 & 45.80 & 43.80 & 5.30 & 0.503 \\
\hline & & 21 & 43.50 & 50.00 & 3.27 & 0.374 \\
\hline \multirow{2}{*}{$\mathrm{Ca}, \mathrm{mg} / \mathrm{dL}$} & \multirow{2}{*}{$6.8-14.8^{2}$} & 7 & 16.50 & 16.56 & 0.45 & 0.952 \\
\hline & & 21 & 16.10 & 15.61 & 0.35 & 0.535 \\
\hline \multirow{2}{*}{$\mathrm{Mg}, \mathrm{mg} / \mathrm{dL}$} & \multirow{2}{*}{$2.0-3.5^{1}$} & 7 & 2.05 & 2.10 & 0.05 & 0.695 \\
\hline & & 21 & 2.45 & 2.14 & 0.08 & 0.069 \\
\hline \multirow{2}{*}{$\mathrm{IP}, \mathrm{mg} / \mathrm{dL}$} & \multirow{2}{*}{$5.5-9.3^{1}$} & 7 & 5.95 & 5.43 & 0.19 & 0.212 \\
\hline & & 21 & 6.6 & 7.53 & 0.31 & 0.173 \\
\hline \multirow{2}{*}{ GOT, UI/L } & \multirow{2}{*}{$22-47^{1}$} & 7 & 25.37 & 42.38 & 6.34 & 0.222 \\
\hline & & 21 & 27.5 & 33.5 & 2.56 & 0.291 \\
\hline \multirow{2}{*}{ GPT, UI/L } & \multirow{2}{*}{$15-65^{1}$} & 7 & 28.88 & 32.63 & 2.01 & 0.407 \\
\hline & & 21 & 60.63 & 53.25 & 2.47 & 0.232 \\
\hline \multirow{2}{*}{ CPK, UI/L } & \multirow{2}{*}{$66-689^{2}$} & 7 & 525.5 & 601.88 & 138.22 & 0.808 \\
\hline & & 21 & 651.75 & 634.13 & 122.17 & 0.135 \\
\hline \multirow{2}{*}{ GGT, UI/L } & \multirow{2}{*}{$31-75^{1}$} & 7 & 50.3 & 55.5 & 12.21 & 0.857 \\
\hline & & 21 & 48.75 & 42.13 & 4.13 & 0.152 \\
\hline
\end{tabular}

C-control diet, ELS:WM - extruded linseed:walnut meal diet, SEM-standard error of mean

${ }^{1}$ Merck Veterinary Manual (Merck\&Co., 2010); ${ }^{2}$ Perri et al. (2017)

${ }^{*} M e a n s$ within rows do not differ significantly $(P>0.05)$

T-Cho, total cholesterol; HDL-C, high-density lipoproteins cholesterol; TG, triglycerides; Ca, calcium; Mg, magnesium; IP, inorganic phosphorus; GOT, glutamyl oxaloacetic transaminase; GPT, glutamyl pyruvic transaminase; CPK, creatine phosphokinase; GGT, gamma-glutamyl transferase

Table 3.

Fecal scores (FS) and incidence of diarrhea (ID) in weaned piglets fed dietary extruded linseed:walnut meal mixture (8:1)

\begin{tabular}{llcccc}
\multirow{2}{*}{ Item } & Period post- & \multicolumn{2}{c}{ Dietary groups } & \multirow{2}{*}{ SEM } & P-value $^{*}$ \\
\cline { 3 - 4 } & weaning (days) & C & ELS:WM & & \\
\multirow{2}{*}{ FS } & 7 & 2.24 & 2.00 & 0.13 & 0.496 \\
& 21 & 2.17 & 1.80 & 0.09 & $0.074^{\prime}$ \\
\multirow{2}{*}{ ID } & 7 & 16.80 & 14.28 & 1.49 & 0.521 \\
& 21 & 5.63 & 5.00 & 0.32 & 0.389 \\
\hline
\end{tabular}

C-control diet, ELS:WM - extruded linseed:walnut meal diet, SEM-standard error of mean

${ }^{*}$ Means within rows do not differ significantly $(P>0.05)$

${ }^{T}$ Tendency to be influenced by the treatment

Table 4.

Fecal microbial populations at 7 days post-weaning $(\log 10 \mathrm{cfu} / \mathrm{g})$

\begin{tabular}{|c|c|c|c|c|}
\hline \multirow[t]{2}{*}{ Item } & \multicolumn{2}{|c|}{ Dietary groups } & \multirow{2}{*}{ SEM } & \multirow[t]{2}{*}{ P-value } \\
\hline & $\mathbf{C}$ & ELS:WM & & \\
\hline Staphylococcus spp. & $6.89^{\mathrm{a}}$ & $6.83^{b}$ & 0.01 & 0.001 \\
\hline E. coli & $10.05^{a}$ & $9.52^{\mathrm{b}}$ & 0.10 & $<0.0001$ \\
\hline Lactobacillus spp. & 9.06 & 9.68 & 0.18 & $0.081^{l}$ \\
\hline Total fungi & $4.20^{a}$ & $3.80^{\mathrm{b}}$ & 0.08 & 0.004 \\
\hline
\end{tabular}

C-control diet, ELS:WM - extruded linseed:walnut meal diet, SEM-standard error of mean

${ }_{a, b}$ Means within a row with no common superscript differ significantly $(P<0.05)$

${ }^{T}$ Tendency to be influenced by the treatment 
of diarrhea as results of dietary mixture addition (Table 3).

\section{CONCLUSIONS}

The results showed that the addition of extruded linseed:walnut meal, 8:1 mixture in weaned piglets diets improve performance and had no significant effect on plasma lipid, mineral and enzyme profile, as important biomarkers of health status. Furthermore, the dietary mixture may be a viable solution to partially replace SBM in piglets' diet due to the positive biochemical response and intestinal health by improving the beneficial bacterial populations.

\section{ACKNOWLEDGEMENTS}

This study was funded by the Romanian Ministry of Research and Innovation through Nucleus Program, grant 1820 0103 and Subprogram 1.2. Institutional Performance, Program 1. Developing National R\&D, National Research and Development and Innovation, Contract no.17 PFE/17.10.2018.

\section{REFERENCES}

1. Barcelo-Coblijn, G., Murphy, E.J. (2009). Alphalinolenic acid and its conversion to longer chain n-3 fatty acids: Benefits for human health and a role in maintaining tissue n-3 fatty acid levels. Progress in Lipid Research, 48, 355-374.

2. Che, L., Zhan, L., Fang, Z., Lin, Y., Yan, T., Wu, D. (2012). Effects of dietary protein sources on growth performance and immune response of weanling pigs. Livestock Science, 148 (1-2), 1-9.

3. Chen, N., Yang, H., Sun, Y., Niu, J., Shuying, L. (2012). Purification and identification of antioxidant peptides from walnut (Juglans regia L.) protein hydrolysates. Peptides, 38, 344-349.

4. Commission Regulation (EU) No. 152 (2009). Official Journal of the European Union, L 54.

5. Directive (EU) No. 63 (2010). Official Journal of the European Union, L 276, 33-79.

6. Farmer, C., Petit, H.V. (2009). Effects of dietary supplementation with different forms of flax in late-gestation and lactation on fatty acid profiles in sows and their piglets. Journal of Animal Science, 87, 26002613.

7. Gheorghe, A., Hăbeanu, M., Lefter, N.A., Grigore, D.M, (2018). Effect of dietary extruded linseed and walnut meal mixture $(8: 1)$ on performance and some plasma biochemical parameter in weaned piglets. BUASVM Cluj-Napoca. Animal Science and Biotechnologies, 75 (2), 121-126.

8. Giang, H.H., Viet, T.Q., Ogle, B., Lindberg, J.E. (2012). Growth performance, digestibility, gut environment and health status in weaned piglets fed a diet supplemented with a complex of lactic acid bacteria alone or in combination with Bacillus subtilis and Saccharomyces boulardii. Livestock Science, $143,132-141$
9. Hanczakowski, P., Szymczak, B., Hanczakowska, E. (2009). Fatty acid profile and cholesterol content of meat from pigs fed different fats. Annals of Animal Science, 9,157-163.

10. Hăbeanu, M., Lefter, N., Gheorghe, A., Al. Nagy, Marin, D., Ropotă, M. (2014). Effects of dietary flaxseed oil on the muscle fatty acid composition in Mangalitsa pigs in an extensive rearing system. South African Journal of Animal Science, 44 (3), 240244.

11. Hăbeanu, M., Lefter, N.A., Gheorghe, A., Tabuc, C., Untea A.E., Surdu, I., Balan, C.G. (2015). Changes in certain serum and faeces parameters in weaned piglets as a response to nutritional stress. South African Journal of Animal Sciences, 45 (2), 164-172.

12. Hăbeanu, M., Lefter, N., Gheorghe, A., Tabuc, C., Dumitru, M., Ciurescu, G., Palade, M. (2017). Effects of dietary peas mixed with linseed (3:1) on the growth performance, enteritis and certain serum parameter in weaned piglets. Food and Feed Research, 44 (2), 173-180. DOI: $10.5937 / F F R 1702173 \mathrm{H}$.

13. Jansman, A.J.M., Wikselaar van P., Wagenaars, C.M.F. (2007). Effects of feeding linseed and linseed expeller meal to newly weaned piglets on growth performance and gut health and function. Livestock Science, 108, 171-174.

14. Kiers, J.L., Meijer, J.C., Nout, M.J.R., Rombouts, F.M., Nabuurs, M.J.A., Meulen van der, J. (2003) Effect of fermented soya beans on diarrhoea and feed efficiency in weaned piglets. Journal of Applied Microbiology, 95, 545-552.

15. Konstantinov, S.R., Awati, A.A., Williams, B.A., Miller, B.G., Jones, P., Stokes, C.R., Akkermans, A.D. Smidt, H., De Vos, W.M. (2006). Postnatal development of the porcine microbiota composition and activities. Environmental Microbiology, 8, 1191-1199.

16. Martínez, M.L., Labuckas, D.O., Lamarque, A.L, Maestri, D.M. (2010). Walnut (Juglans regia L.): genetic resources, chemistry, by-pro-ducts. Journal of Science and Food Agriculture, 90, 1959-1967.

17. Merck\&Co. (2010). The Merck Veterinary Manual, $10^{\text {th }}$ ed., Merck Co., Inc., Kenilworth, NJ, USA.

18. Nyachoti, C.M., Omogbenigun, F.O., Rademacher, M., Blank, G. (2006). Performance responses and indicators of gastrointestinal health in early weaned pigs fed low-protein amino acid-supplemented diets. Journal of Animal Science, 84 (1), 125-134.

19. NRC (1998). Nutrient Requirements of Swine, Revised $10^{\text {th }}$ ed., National Academy Press, Washington, DC.

20. Perri, A.M., O'Sullivan, T.L., Harding, J.C.S, Wood, R.D., Friendship, R.M. (2017). Hematology and biochemistry reference intervals for Ontario commercial nursing pigs close to the time of weaning. Canadian Veterinary Journal, 58 (4), 371-376.

21. Pluske, J.R., Williams, I.H., Hampson, D.J. (1997). Factors influencing the structure and function of the small intestine in the weaned pig: a review. Livestock Production Science, 51, 215-236.

22. Pluske, J.R., D.W. Pethick, D.E. Hopwood, D.J. Hampson. (2003). Nutritional influences on some major enteric bacterial diseases of pig. Nutrition Research Reviews, 15 (2), 333-371.

23. SPSS (2011). Statistics v. 20.0., IBM, SPSS, Inc., USA.

24. TOPIGS (2012). Feed Manual Topigs. Topigs, Norsvin, The Netherlands.

25. Taranu, I., Gras, M., Pistol, G.C., Motiu, M., Marin, D.E., Lefter, N., Ropota, M., Habeanu, M. (2014). w-3 PUFA rich camelina oil by-pro-ducts improve the systemic metabolism and spleen cell functions in fattening pigs. PLOS One, 10, 9(10):e110-186. 
doi: 10.1371/journal.pone.0110186.

26. Zhan, Z.P., Huang, F.R., Luo, J., Dai, J.J., Yan, X.H. (2009). Duration of feeding linseed diet influences expression of inflammation-related genes and growth performance of growing-finishing barrows. Journal of Animal Science, 87, 603-611.

27. Wellock, I.J., Fortomaris, P.D., Houdijk, J.G., Kyriazakis, I. (2008). Effects of dietary protein supply, weaning age and experimental enterotoxigenic Esche- richia coli infection on newly weaned pigs' health. Animal, 2 (6), 834-842.

28. Wen, X., Wang, L., Zheng, C., Yang, X., Ma, X., Wu, Y., Chen, Z., Jiang, Z. (2018). Fecal scores and microbial metabolites in weaned piglets fed different protein sources and levels. Animal Nutrition, 4, 31-36.

29. Winnicka, A. (2011). Reference Values of Basic Laboratory Research in Veterinary Sciences, $1^{\text {st }} \mathrm{ed}$, Warsaw University of Agriculture (SGGW Warszawa), SGGW Warszawa.

\title{
АСПЕКТИ БИОХЕМИЈСКИХ ПАРАМЕТАРА КРВНЕ ПЛАЗМЕ И ИНТЕСТИНАЛНОГ ЗДРАВЉА ОДЛУЧЕНИХ ПРАСАДИ ХРАЊЕНИХ МЕШАВИНОМ ЕКСТРУДИРАНОГ ЛАНЕНОГ СЕМЕНА И САЧМЕ ОРАХА
}

\author{
Анка Георге*, Михаела Хабеану, Николета А. Лефтер, Михаела Думитру, Даниела М. Григоре \\ Национални истраживачко-развојни институт за биологију и исхрану животиња (INCDBNA), \\ 077015 Балотешти, Калеа Букурешти 1, Румунија
}

Сажетак: У оквиру овог истраживања испитиван је утицај исхране прасади смешом екструдираног семена лана (ELS) и сачме ораха (WM) у односу 8:1 на одабране параметре крвне плазме и здравља црева код одлучених јединки. Четрдесет прасади (Topigs хибрид) телесне масе (BW) 8,02 \pm 0,82 кг, старости $30 \pm 3$ дана, подељено је у 2 третмана: контролни (C, исхрана на бази кукуруза, тритикалеа и сојине сачме (SBM)) и експериментални (смешом у којој смеша екструдираног семена лана и ораха, у односу 8:1, делимично замењује SBM). Узорци крви су сакупљани 7-ог и 21-ог дана након одлучивања прасади (PW). За одређивање липида у крвној плазми (укупни холестерол, T-Chol; ХДЛ-холестерол, HDL-C; триглицериди, TG), минералног и ензимског профила коришћен је хемијски анализатор. Микробиолошке популације из фекалних узорака одређиване су бројањем колонија добијених на одабраним медијумима. На основу добијених резултата није установљен ефекат примењене мешавине у исхрани одлучене прасади (PW) на параметре крвне плазме узорковане 7-ог и 21-ог дана огледа $(P>0,05)$. Резултати истраживања показали су да је концентрација HDL-C у плазми PW била у позитивној корелацији са садржајем алфа-линоленских (АЛА) масних киселина након 7-ог дана $(r=0,94, \mathrm{P}<0,0001)$ и 21-ог дана огледа $(r=0,89, \mathrm{P}<0,0001)$, док је 21-ог дана испитивана мешавина утицала на садржај T-Chol $(r=0,52, \mathrm{P}=0,08)$ и TG $(r=0,54, \mathrm{P}=0,07)$. Фекални скор (FS) код PW је редукован 7-ог дана (P>0,05), а 21-ог дана је уочена тенденција смањења FS као последице додавања експерименталне смеше у исхрани прасади $(P=0,07)$. Тестирана смеша за исхрану прасади је позитивно је утицала на популације фрекалних микроорганизама и то смањењем Staphylococcus spp. $(P=0,001)$, E. coli $(P<0,0001)$ и гљивица $(P=0,004)$, а такође је уочена тенденција повећања врста Lactobacillus spp. $(P=0,08)$. У закључку, испитивана смеша може бити алтернатива за делимичну замену SBM у исхрани прасади због позитивног биохемијског одговора и доброг утицаја на здравље црева.

Кључне речи: екструдирано храниво, хранљива смеша, ентеритис, фрекална микрофолора, параметри крвне плазме, прасад

Received: 11 December 2018

Received in revised form: 14 January 2019

Accepted: 1 February 2019 